\title{
DO FIRM FAILURE PROCESSES DIFFER ACROSS COUNTRIES: EVIDENCE FROM FINLAND AND ESTONIA
}

\author{
Erkki K. LAITINEN ${ }^{1}$, Oliver LUKASON ${ }^{2}$ \\ ${ }^{1}$ Department of Accounting and Finance, Faculty of Business Studies, \\ University of Vaasa, Wolffintie 34, 65200 Vaasa, Finland \\ ${ }^{2}$ Chair of International Business and Innovation, Faculty of Economics and Business \\ Administration, University of Tartu, Narva road 4, 51009 Tartu, Estonia \\ E-mails: 1ekla@uwasa.fi; ${ }^{2}$ oliver.lukason@ut.ee (corresponding author)
}

Received 30 November 2012; accepted 28 March 2013

\begin{abstract}
This study considers the novel topic of comparing firm failure processes between different countries. For seventy bankrupt Finnish firms corresponding pairs are found among Estonian bankrupt firms based on industry, size and time of bankruptcy. Despite the similarity of firms from two countries, the analysis shows remarkable differences in both pre-failure financial data and reasons for failure. Based only on financial data, five failure processes are detected for Finnish and six for Estonian firms. Established failure processes associate with different failure reasons. The study contributes to literature by showing that for similar companies failure processes can differ across countries. In practice, the established information about different failure processes can be applied when building or using bankruptcy prediction models.
\end{abstract}

Keywords: firm failure process, failure causes, financial ratios, bankruptcy, comparative analysis, Estonia, Finland.

JEL Classifications: G33, M21, O57, P29.

\section{Introduction}

Lengthy research in the field of firm failure has created a multitude of studies covering various facets, such as prediction, reasons, processes and aftermath of corporate collapse. While some subsets (see e.g. Pretorius (2008) for the classification of failure studies) of relevant literature have been thoroughly developed (e.g. bankruptcy prediction), then others have been rather scarcely (e.g. detection of failure processes and patterns, interconnection of reasons for failure and financial data). Only a few studies can be found focusing on international comparison (e.g. Altman, Narayanan 1997; Lussier, Halabi 2010), some of which indicate a high similarity of failure predictors across countries (also developed and developing countries). In contrast, studies validating the efficiency of bankruptcy models from different environments using local data (e.g. Ooghe, Balcaen 2007) have shown that there is a high variation in prediction abilities. The core of failure studies seems to be focused on developed countries (see e.g. Dimitras et al. 
1996; Altman, Narayanan 1997), with transition and developing countries receiving relatively low attention. Literature remarkably lacks studies comparing similar firms from different environments and no studies were found contrasting failure processes (based on financial and non-financial variables) in different countries.

Derived from the above, the objective of this study is to extract taxonomies of failure processes and find out how they differ based on the data of Estonian and Finnish firms. These two countries have been chosen as they are good pairs for comparison as, for instance, they share similar historical, cultural and linguistic backgrounds, location in the same region, comparable legislation, high economic ties and other common features. One of the main differences between these countries is the stage of economy, Estonia being not as developed as Finland. In this study, seventy Finnish and Estonian bankrupt firms are compared with each other. For mitigating the role of size, industry and time on studied failure processes, a pairwise selection of bankrupt firms is applied. Several statistical tools will be used to research the presence of different failure processes and their inter-country similarities based on financial variables and reasons of insolvencies. We consider this study pioneering since it is the first one contrasting failure processes of carefully selected country pairs.

The paper is structured as follows. The introductory section is followed by a chapter describing framework for the analysis, which outlines the core of available literature and gives an insight about the two countries chosen for analysis. This is followed by the empirical section, outlining how similar firms are detected, what financial variables are chosen for analysis based on the literature review, and how information about reasons is obtained and systemized. The empirical section also includes descriptive statistics of studied variables and tests of their similarity between the two countries. The given descriptive study is followed by a logistic regression analysis to show whether and which variables discriminate between Finnish and Estonian firms. Thereafter, the analysis is devoted to studying failure processes, based on only financial variables and the combination of financial variables and reasons for failure. The paper ends with conclusions, which include a discussion of results and study limitations, but also domains of future research.

\section{Framework for the analysis}

\subsection{Prior failure studies}

Failure studies are characterized by high divergence in the terminology used. For instance, terms such as trajectory (Argenti 1976), patterns (Crutzen, Van Caillie 2010), process (Ooghe, De Prijcker 2008; Laitinen 1991), pathways (Moulton et al. 1996) and extinction (Sheppard, Chowdhury 2005) have been applied for similar concepts, whereas different authors have even treated the same terms varyingly. A number of studies break the failure process into phases and apply either financial variables (Laitinen 1993), reasons for failure (Argenti 1976; Richardson et al. 1994) or both of them (Ooghe, De Prijcker 2008) to describe decline. There are a few studies focusing on taxonomies of different failure processes, among which the usage of only financial variables (Laitinen 1991), only reasons for failure (Crutzen, Van Caillie 2010) and both of them integrated (Hambrick, D'Aveni 1988) can be found, a gap in some studies being thorough empirical 
validation. Still, as stated in Altman and Narayanan (1997), causal studies based on reasons for failure are relatively rare.

Some research has focused on cross-country comparisons of reasons for failure or financial characteristics, but mostly datasets from a single country have been applied. Studies (Lussier, Pfeifer 2001; Lussier, Halabi 2010) have indicated that non-financial failure predictors in developed countries are the same as in developing ones, although it is not clear whether similar failed firms in different environments witness the same predictors. Despite remarkable similarities being found for financial predictors of failure in different environments (see e.g. Bellovary et al. 2007), outcomes have also shown high controversy, among others being dependent on different notions of failure definitions (Fredland, Morris 1976; Cochran 1981; Everett, Watson 1999) and theoretical foundations of corporate collapse (Daily 1994; Mellahi, Wilkinson 2004), but also differences in the amount and nature of data used (Altman, Narayanan 1997; Bellovary et al. 2007). Based on Mellahi and Wilkinson (2004), it could be assumed that failure of similar firms in different environments varies. There are still some unsolved issues in light of the current literature. Although studies have proven the presence of certain failure taxonomies based on the example of a specific country, it is not clear whether that taxonomy will be significant with a similar dataset from a different country. When aspiring towards a common theoretical framework of firm failure processes, this is an important task to fulfil. In this study, our aim is to contribute to failure research by integrating analyses of financial variables and reasons for failure as to extract taxonomy of failure processes and comparing these processes across two different countries.

\subsection{Finland and Estonia}

The paper uses data of bankrupt firms from two neighbouring European Union (EU) countries, Finland and Estonia. Estonia, which regained its independence in 1991, was previously occupied by the Soviet Union, and therefore according to different classifications belongs to the transition (EBRD 2011), transformation (Kornai 2006), post-transition (Masso, Vahter 2008), developing or "Western European" (World Economic Forum 2012) country category. Similarities between EU15 countries and Estonia have been found in several studies (see e.g. Baležentis et al. 2010). Finland on the contrary is a developed economy, being independent since 1917, i.e. a year before Estonia gained its independence. Although both countries are member states of the EU and European Monetary Union, Estonia considerably lags behind in several macroeconomic indicators, e.g. according to Eurostat database (2012), for 2011 real GDP per capita (in euros) was 9,000 in Estonia and 31,500 in Finland, there was around a three times difference in resource productivity. Despite these discrepancies, those two countries have highly connected economies. Finland represents Estonia's second largest export and largest import partner as of 2011, a relatively large proportion of Estonian workforce is employed in Finland and many Estonian firms are Finnish owned.

Leaving the selected economic indicators aside, Estonia and Finland are highly comparable countries. This conclusion could be drawn by viewing numerous indicators, such as history, culture, language, but also legislation. To elaborate some of the previously noted 
factors, Estonia and Finland are very similar through Hofstede (2012) cultural dimensions, have less than twofold difference in population density, have both been influenced in the past by Swedish and Russian rule. Regarding legislation, the two countries have relatively similar business and bankruptcy codes, for the latter also concerning the opening of proceedings, which makes the comparison of cases possible. Despite the similarity of laws, World Bank (2012) indicates Finland to have very effective insolvency resolution procedures, whereas Estonia is substantially lagging behind (the creditor claim satisfaction rates $89.1 \%$ and $36.9 \%$ respectively). One reason for this different efficiency, which is common to other transition countries as well (see World Bank 2012), could be varying failure processes. Still, in current study we do not measure the impact of differences in the characteristics of those two countries on failure process, as this exceeds the objective of the study and demands a completely different methodological and empirical background.

\subsection{Hypothesis}

Although literature does not unambiguously provide, whether failure processes should be similar or different through countries, more evidence supports their diversity. Derived from previous, we set the general research hypothesis that there are differences in the failure processes between countries. As the specific research hypothesis we test whether firm failure processes are different between Estonia and Finland. The hypothesis will be assessed in two different domains of failure processes: based on only financial variables and secondly, based on the combination of reasons for failure and financial variables. The latter domain first of all demands checking, whether the combination of reasons for failure and financial data will lead to distinct failure processes at all. Besides the previously given, differences and similarities between all financial variables and reasons for failure in the two countries will be outlined.

\section{Data and descriptive statistics}

\subsection{Sampling of firms}

The analysis begins with a sample of 70 Finnish firms which are randomly chosen from different sizes, industries and time periods. For those cases both bankruptcy reasons and pre-bankruptcy financial data could be obtained. In the Finnish sample there are not very small firms, partly because such firms do not publish financial statements and it is difficult to uncover definite reasons for bankruptcy using public sources. For each Finnish firm an Estonian mate is found using following criteria: firstly industry (NACE), then size (number of workers) and finally bankruptcy time (year). NACE codes are matched as specifically as possible, whereas the database includes 32 firms from production, 14 from sales and 24 from services sectors. Bankruptcy years of firms in analysis range from years 2002 to 2009. Pre-bankruptcy median of workers is 18 for Finnish and 14 for Estonian firms, although lower and upper quartiles differ more. The median of net sales per worker is also $40 \%$ higher in Finland. Given pairwise selection at least partly eliminates the effects of size, industry and time on the results. Still, the likelihood of finding two identical bankrupt firms from two countries is very small. Number of workers is the best option for matching 
the size of firms, as the values of total assets and net sales (which are often used in matching) are directly affected by the failure process, i.e. their values can reduce a lot before bankruptcy is declared. Moreover, as net sales and total assets are important variables in describing the failure process in current study, they cannot be used twice in analysis.

\subsection{Selection of financial variables}

Bankruptcy research mostly relies on empirical studies and despite the presence of theoretical foundations how to choose variables for prediction models, they are mostly chosen empirically (Balcaen, Ooghe 2006; Lensberg et al. 2006). Although the probabilistic bankruptcy theory (see Scott 1981) shows how to choose and model predictors of failure, it repeats the logic of some previously established bankruptcy models, that two types of variables should be included in models - static variables reflecting financial position at a certain point of time and dynamic variables reflecting cash flows. When combining bankruptcy theory and empirical evidence, then the following variables have proven to be important predictors of corporate collapse (Scott 1981; Jones 1987; Laitinen 1991; Dimitras et al. 1996; Altman, Narayanan 1997): capital structure (i.e. leverage or solidity), creation of profit (i.e. profitability), ability to pay outstanding debt (i.e. liquidity), creation of free cash flows and size.

Based on prior studies outlined above, twelve variables are selected to represent profitability, liquidity, solidity, cash flows and size. Four of these variables measure size (i.e. net sales and total assets, but also their natural logarithms), which are also reflected by two variables showing their change in the year before the bankruptcy (see Table 1). The other variables include six financial ratios measured at two points of time, one year and two years prior to bankruptcy (see Table 1). In this way, the dynamics of the failure process is in a simple way incorporated to the analysis. In total, 18 variables are used. Prior bankruptcy studies show that the symptoms of failure are discernible only in the few years before the event (see e.g. D'Aveni 1989). Therefore, and to limit the number of variables, this study focuses on the financial situation one and two years prior to bankruptcy. Table 1 presents descriptive statistics of financial variables for Finnish and Estonian bankrupt firms. The distributions of a number of financial variables are skewed and therefore nonparametric tests are adopted. The Wilcoxon Signed Rank Test results show that financial data of firms from two countries is different, namely Estonian firms are smaller, show higher profitability (return on investment ratio), lower liquidity (quick ratio), and lower debt intensity (debt to net sales).

\subsection{Describing the reasons for bankruptcy}

The reasons for bankruptcies in these countries are initially based on different classifications, making the comparison of reasons difficult unless classifications are unified. In Finland, the reasons were extracted from court documents and other information sources, i.e. published interviews with management, annual reports and other publicly available sources. Based on information obtained from them a detailed report on each bankruptcy and reasons behind it was written. In this way, the reasons were initially classified as 7 external reasons and 48 internal reasons. In Estonia, the reasons were directly taken 
Table 1. Descriptive statistics of financial variables for Finnish and Estonian bankrupt firms

\begin{tabular}{|c|c|c|c|c|c|}
\hline \multirow[t]{2}{*}{ Financial variable } & \multicolumn{2}{|c|}{ Finnish bankrupt firms } & \multicolumn{2}{|c|}{$\begin{array}{l}\text { Estonian bankrupt } \\
\text { firms }\end{array}$} & \multirow{2}{*}{$\begin{array}{l}\text { Wilcoxon } \\
\text { p-value }\end{array}$} \\
\hline & Mean & Median & Mean & Median & \\
\hline Net sales $(\mathrm{t}-1)$, Euro & $5,633,633.3$ & $2,217,747.0$ & $1,449,879.0$ & $201,082.2$ & 0.000 \\
\hline Total assets $(\mathrm{t}-1)$, Euro & $3,049,917.4$ & $1,507,745.0$ & $637,535.4$ & $55,640.5$ & 0.000 \\
\hline $\operatorname{Ln}(\operatorname{Net} \operatorname{sales}(\mathrm{t}-1))$ & 14.3915 & 14.6105 & 12.4820 & 12.2113 & 0.000 \\
\hline $\operatorname{Ln}($ Total assets $(\mathrm{t}-1))$ & 14.0697 & 14.2243 & 11.0837 & 10.9248 & 0.000 \\
\hline Change in net sales $(\mathrm{t}-1), \%$ & -2.8443 & -5.0000 & -10.9451 & -14.6116 & 0.381 \\
\hline $\begin{array}{l}\text { Change in total assets } \\
(\mathrm{t}-1), \%\end{array}$ & 1.9205 & -6.5601 & -17.2298 & -17.2326 & 0.016 \\
\hline $\begin{array}{l}\text { Return on investment ratio } \\
(\mathrm{t}-1), \%\end{array}$ & -31.0771 & -22.5500 & 1.0738 & 0.1660 & 0.000 \\
\hline $\begin{array}{l}\text { Return on investment ratio } \\
(\mathrm{t}-2), \%\end{array}$ & -15.3786 & -10.5000 & -2.4511 & 0.0943 & 0.008 \\
\hline $\begin{array}{l}\text { Net income to net sales } \\
(\mathrm{t}-1), \%\end{array}$ & -25.6571 & -10.8000 & -18.7163 & -6.6418 & 0.108 \\
\hline $\begin{array}{l}\text { Net income to net sales } \\
(\mathrm{t}-2), \%\end{array}$ & -18.7143 & -6.2500 & -7.7589 & -1.1759 & 0.011 \\
\hline $\begin{array}{l}\text { Traditional cash flow to net } \\
\text { sales }(t-1), \%\end{array}$ & -21.2771 & -5.5000 & -14.8456 & -6.6418 & 0.275 \\
\hline $\begin{array}{l}\text { Traditional cash flow to net } \\
\text { sales }(t-2), \%\end{array}$ & -14.3971 & -1.3000 & -4.6510 & -0.3970 & 0.066 \\
\hline Quick ratio $(\mathrm{t}-1)$ & 1.0700 & 0.4500 & 0.1328 & 0.0150 & 0.000 \\
\hline Quick ratio $(\mathrm{t}-2)$ & 0.8686 & 0.5500 & 0.1746 & 0.0410 & 0.000 \\
\hline Debt to net sales $(t-1), \%$ & 128.5586 & 68.4500 & 77.0996 & 33.7101 & 0.003 \\
\hline Debt to net sales $(t-2), \%$ & 99.4357 & 49.9500 & 50.2743 & 31.4292 & 0.002 \\
\hline Equity ratio $(\mathrm{t}-1), \%$ & -23.4686 & -14.8000 & -31.7923 & -23.7122 & 0.359 \\
\hline Equity ratio $(\mathrm{t}-2), \%$ & -1.9843 & 2.3000 & -2.7167 & 8.8294 & 0.846 \\
\hline
\end{tabular}

Notes: $\mathrm{t}-1=$ One year prior to bankruptcy; $\mathrm{t}-2=$ Two years prior to bankruptcy. Wilcoxon $\mathrm{p}$-value $=$ Significance level of the Wilcoxon Signed Rank Test to test the equality of the median of differences between Finnish and Estonian firms.

from the court judgments, as the Estonian Bankruptcy Act obliges the trustee to state insolvency reasons there. In the selected Estonian cases, 16 different reasons used by trustees were detected. In Finland, the most frequent reason for bankruptcy deals with financial management and control (internal reason) while in Estonia it is associated with changes at the market, specifically demand and competition (external reasons).

For making data comparable between Finland and Estonia, a classification to cover the whole spectrum of possible failure reasons was synthesized based on several different 
taxonomies (i.e. Boyle, Desai 1991; Baldwin et al. 1997; Argenti 1976; Gaskill et al. 1993; Mellahi, Wilkinson 2004; Crutzen, Van Caillie 2010). This classification consists of five classes, two classes for external reasons (namely general and specific causes), and three classes for internal reasons (namely general management, financial management and control, and operations management). The classes of external reasons show that two different types of reasons contribute to failure: some specific event or so-called external shock and overall changes at the market where the firm functions, the latter of which can arise from the general economic conditions, demand or supply of goods. Reasons from inside the firm (i.e. internal reasons) are broken into three classes: general, financial and operations management issues. While general management problems point to overall deficiencies in running the firm (e.g. lack of proper education, overoptimism, poor business planning), the two other classes reflect specific functional deficiencies.

Initial data was re-classified by distributing all reasons (i.e. 55 Finnish reasons and 16 Estonian reasons) to given five classes and therefore the maximum number of reasons in each new class usually exceeded unity. Because the Finnish original classification consisted of a large number of reasons, the maximum frequency in a new class can be high which weakens the comparability. In order to increase comparability, two transformations were implemented. Firstly, the sum of frequencies for each class was constrained by unity (i.e., when one or more initial reasons belonging to given class is reported, then the value is 1 , and otherwise it is 0 ) and after that the mean frequency directly tells the proportion of the firms reporting the reason belonging to relevant class. Still, a problem resulting from first transformation for further statistical analysis is that all firms have values for all reason classes either 0 or 1 . In order to solve that issue, new frequencies were re-scaled by dividing them with the initial maximum frequency for that class, after which the value for each firm in both countries varies between 0 and 1. The resulted re-scaled frequency of re-classified bankruptcy reasons can be seen in Table 2, but in given table and following text they are noted shortly as reasons (variables) of bankruptcy.

\section{Comparison of Finnish and Estonian firms}

\subsection{Logistic regression analysis}

In the present study, logistic regression analysis (LRA) will be applied to estimate the classification models of Finnish and Estonian bankrupt firms, based firstly on financial variables and secondly on reasons of bankruptcy. For this estimation, the dependent variable $Y=1$ when the firm is from Finland and $Y=0$ when it is from Estonia. The application of LRA results in a logit score $L$ for each firm, which is in turn used to determine the conditional probability to be a Finnish bankrupt firm as:

$$
p(Y=1 \mid X)=\frac{1}{1+e^{-L}}=\frac{1}{1+e^{-\left(b_{0}+b_{1} x_{1} \ldots+b_{n} x_{n}\right)}},
$$

where $b_{\mathrm{i}}(i=0, \ldots, n)$ are coefficients and $n$ is the number of independent variables $x_{\mathrm{i}}(i=1, \ldots, n)$. 


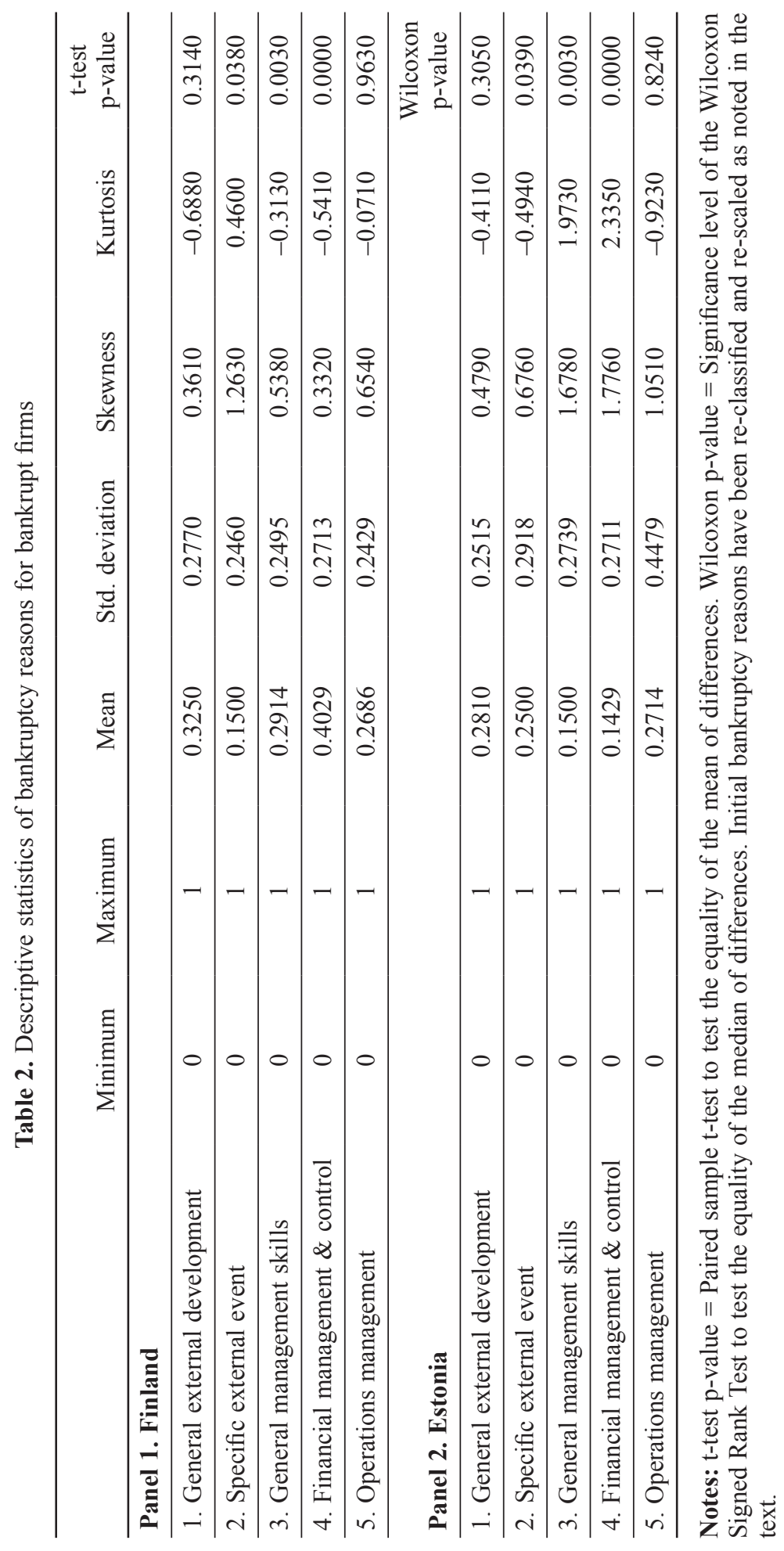


The LR models are estimated by the maximum likelihood method in the Statistical Package for the Social Sciences (SPSS). The linearity of logit is assessed by the HosmerLemeshow test. The statistical significance of the coefficients is tested by the Wald test. The strength of association is mainly assessed by the Nagelkerke R Square. The classification accuracy of the models is evaluated by the per cent of Type I and II errors in the Lachenbruch cross-validated sample.

\subsection{Empirical results}

LRA is used here to identify the differences in financial variables and in bankruptcy reasons between Finnish and Estonian bankrupt firms. Since the number of financial variables is high, a stepwise LRA is used for these variables. Table 3 shows the resulting final LR model based on five variables (after five steps). It shows that Finnish and Estonian bankrupt firms can be discriminated by a very high accuracy. In the model, size, profitability, liquidity, and solidity all show an equal significance (Panel 2 of Table 3). In fact, the final model includes quick ratios from both the first and second year before bankruptcy, referring to dynamics of liquidity. The equity ratio refers to solidity two years prior to bankruptcy, showing that differences in solidity diminish when the failure process is going ahead. The results show that the probability to belong to the Finnish bankrupt firms' group is higher, the higher the size and liquidity (both one year prior to bankruptcy), and the lower the profitability and solidity (two years prior to bankruptcy) are. The smaller size of Estonian firms reflected by the natural logarithm of pre-bankruptcy total assets also reflects the fact that before insolvency is declared, Estonian firms have exhausted remarkably more of their assets, which is also supported by lower claim satisfaction rate in Estonia. The Nagelkerke $\mathrm{R}^{2}$ (Panel 1 of Table 3) shows that the strength of the dependence is extremely high. In addition, the LR model correctly classifies as many as $95.7 \%$ of the sample firms (Panel 3 of Table 3 ). The rate of classification is very high for both Finnish and Estonian firms. Thus, the LR results imply that there are significant differences in pre-failure financial processes of bankrupt firms across the two countries.

Table 4 shows the results of the LR analysis based on the reasons for bankruptcy. The results show that the model is not as efficient as for the financial variables (Panels 1 and 3 of Table 4 compared to Panels 1 and 3 in Table 3). However, two of the five reason variables are statistically significant in discriminating between Finnish and Estonian bankrupt firms. The model shows that the probability to belong to the group of Finnish firms is higher the more the reasons are traced to financial management and control and general management skills (Panel 2 of Table 4). The logistic model correctly classifies about $72.1 \%$ of the firms into the groups of Finnish and Estonian bankrupt firms (Panel 3 of Table 4). The rate of correct classifications is over $70 \%$ for both Finnish and Estonian bankrupt firms.

The degree of multicollinearity in the logistic models of financial variables and reason variables was measured using the VIF (variance inflation factor) measure of multicollinearity. For all variables in the both regression equations, VIF was close to unity referring to a very low degree of multicollinearity. Therefore, multicollinearity is not an issue when interpreting the logistic regression results. 
Table 3. Logistic regression model of financial variables (Estonian and Finnish bankrupt firms)

Panel 1. Goodness of fit of the financial variables model

\begin{tabular}{lcccc}
\hline-2 Log likelihood & Cox \& Snell R & Nagelkerke R & $\begin{array}{c}\text { Hosmer-Lemeshow } \\
\text { Chi-square }\end{array}$ & p-value \\
\hline 23.6430 & 0.7040 & 0.9390 & 0.1230 & 1.0000 \\
\hline Panel 2. Financial variables model (stepwise) $(\mathrm{Y}=0$ when Estonia, 1 & when Finland) & \\
\hline Financial variable & Coefficient & Standard error & Wald test statistic & p-value \\
\hline Ln(Total assets $(\mathrm{t}-1))$ & 3.4050 & 1.3300 & 6.5560 & 0.0100 \\
\hline $\begin{array}{l}\text { Return on investment ratio } \\
(\mathrm{t}-1), \%\end{array}$ & -0.2410 & 0.0960 & 6.2720 & 0.0120 \\
\hline Quick ratio ( -1$)$ & 7.8060 & 3.3260 & 5.5080 & 0.0190 \\
\hline Quick ratio $(\mathrm{t}-2)$ & 10.4750 & 4.2390 & 6.1080 & 0.0130 \\
\hline Equity ratio $(\mathrm{t}-2), \%$ & -0.1430 & 0.0590 & 5.9320 & 0.0150 \\
\hline Constant & -50.5940 & 19.6420 & 6.6350 & 0.0100 \\
\hline
\end{tabular}

Note: Financial variables from Table 1 have been applied in analysis, except for net sales $(\mathrm{t}-1)$ and total assets $(\mathrm{t}-1)$.

Panel 3. Classification accuracy of financial variables model (cross-validated)

\begin{tabular}{lcccc}
\hline Country & Classified as & Estonia & Finland & Percent of correct \\
\hline Estonia & 68 & 2 & 97.1 \\
\hline Finland & 4 & 66 & 94.3 \\
\hline Overall percentage & & & 95.7 \\
\hline
\end{tabular}

\section{Development of a taxonomy of failure processes}

\subsection{Clustering by factor analysis}

As noted in the literature review, firms follow different (financial) failure processes (Laitinen 1991; Balcaen, Ooghe 2006) and given processes could be associated with different causes of failure (Ooghe, De Prijcker 2008). Thus, the aim is to cluster Finnish and Estonian bankrupt firms into homogenous groups on the basis of financial ratios. As almost all bankrupt firms are characterized by very poor financial ratios before the event, it is difficult to reveal relevant subgroups by traditional clustering methods. These clustering methods (namely, $k$-means clustering and hierarchical clustering) in this situation resulted in finding two or three groups, where the largest group included about $95 \%$ of observations. However, they do not pay attention to the dynamics behind the set of variables. Therefore, another statistical method (i.e. factor analysis) was applied to find homogenous groups. First, the information included in the set of variables was reduced 
Table 4. Logistic regression model of bankruptcy reason variables

(Estonian and Finnish bankrupt firms)

Panel 1. Goodness of fit of the bankruptcy reason variables model ( $\mathrm{Y}=0$ when Estonia, 1 when Finland)

\begin{tabular}{ccccc}
\hline -2 Log likelihood & Cox \& Snell R & Nagelkerke R & $\begin{array}{c}\text { Hosmer-Lemeshow } \\
\text { Chi-square }\end{array}$ & p-value \\
\hline 154.4490 & 0.2470 & 0.3290 & 20.7130 & 0.0080 \\
\hline
\end{tabular}

Panel 2. Bankruptcy reason variables model

\begin{tabular}{lcccc}
\hline Bankruptcy reason & Coefficient & $\begin{array}{c}\text { Standard } \\
\text { error }\end{array}$ & $\begin{array}{c}\text { Wald test } \\
\text { statistic }\end{array}$ & p-value \\
\hline 1. General external development & 1.2180 & 0.7950 & 2.3490 & 0.1250 \\
\hline 2. Specific external event & -0.6360 & 0.7230 & 0.7740 & 0.3790 \\
\hline 3. General management skills & 2.0650 & 0.7680 & 7.2320 & 0.0070 \\
\hline 4. Financial management \& control & 3.3900 & 0.7530 & 20.2490 & 0.0000 \\
\hline 5. Operations management & 0.2790 & 0.5540 & 0.2540 & 0.6140 \\
\hline Constant & -1.6600 & 0.5050 & 10.8110 & 0.0010 \\
\hline
\end{tabular}

Note: Bankruptcy reason variables from Table 2 have been applied in analysis.

Panel 3. Classification accuracy of bankruptcy reason variables model (cross-validated)

\begin{tabular}{|c|c|c|c|}
\hline Country $\quad$ Classified as & Estonia & Finland & Percent of correct \\
\hline Estonia & 49 & 21 & 70.0 \\
\hline Finland & 18 & 52 & 74.3 \\
\hline Overall percentage & & & 72.1 \\
\hline
\end{tabular}

and used to find independent latent dimensions by factor analysis. These independent dimensions were further used to extract a taxonomy of bankrupt firms to illustrate the differences in their financial characteristics.

With clustering the firms, the objective was to find a taxonomy which would be interesting and useful in comparing Estonian and Finnish bankrupted companies. Therefore, factor analysis was used to extract the most important latent characteristics based on the loadings of the original 16 financial variables (the two unlogarithmed size variables were not applied in analysis). In this way, we were able to find five latent variables characterizing Finnish firms while the number of significant latent variables for Estonian firms was six. Because of the orthogonal Varimax rotation, these country-specific latent variables were independent of each other and thus connected to different characteristics of firms. Because the factor scores are standardized, they efficiently describe the relative importance of each 
characteristic to the firm. Because each factor describes a significant characteristic of a set of characteristics which are independent of each other, the highest factor score is associated with the most important characteristic of a specific firm. We have used this, the most important characteristic, to determine the group of a firm. In that way, we were able to extract groups that are interesting, describe different important characteristics, and are also independent of each other, which is essential for a good taxonomy.

The number of the factors was decided on the basis of the scree test so that the eigenvalue of each extracted component (factor) exceeded unity. For the Finnish firms, the extracted five-factor solution explained $81.5 \%$ of the total variation of all sixteen financial variables. For the Estonian firms, this proportion for the six-factor solution was $81.9 \%$. Thus, the extracted factors explain a very high proportion of total variation and therefore catch the main part of information included in the financial ratios. One way to interpret the five- and six-factor solutions for Finland and Estonia is by using the loadings of the factors (see Appendix 1). Namely, high (absolute) loadings on two financial variables show that the variables are strongly associated, firstly, with each other and, secondly, with the hidden dimension behind the factor solution. When factor scores are used in clustering, the firms with high (absolute) values for the variables are classified into the group associated with the factor. Current study implements a second (ex post) way to interpret the factor solutions by comparing the financial characteristics of the bankrupt firms in different groups. This interpretation can be done by the median values of the variables presented in Table 5 for each group.

\subsection{Interpretation of the clusters}

Panel 1 of Table 5 shows the median values for Finnish groups. The first group (17.1\%) is characterized by a small firm size, strong negative growth, and very low profitability. In addition, cash flow and equity ratios have dramatically declined in the first year prior to bankruptcy. The second group (32.9\%) reflects an average, steady failing firm. In this group, all financial ratios reflect a poor financial situation (profitability, liquidity, cash flow, solidity), but the ratios do not show any extreme values and are quite similar for both years prior to bankruptcy. The third group (30.0\%) includes large unsteady firms. For these firms, most of the financial ratios have dramatically declined in the first year prior to bankruptcy. The fourth group $(7.1 \%)$ is a small group with very peculiar characteristics. The firms in this group report a very low profitability and cash flow, but at the same time a very high liquidity and solidity. The financial ratios (quick ratio, equity ratios) are comparable with average non-failing firms. Therefore, it could be expected that the reasons of bankruptcy for the firms are not typical. The bankruptcy of this type of firm is difficult to predict using financial ratios. The last group (12.9\%) consists of small firms when measured by net sales. However, these firms have an exceptionally large amount of total assets in relation to net sales. These firms have grown very rapidly both in net sales and total assets. Their financial situation is unsteady and dramatically declined in the last year as measured by profitability, cash flow, and solidity. 


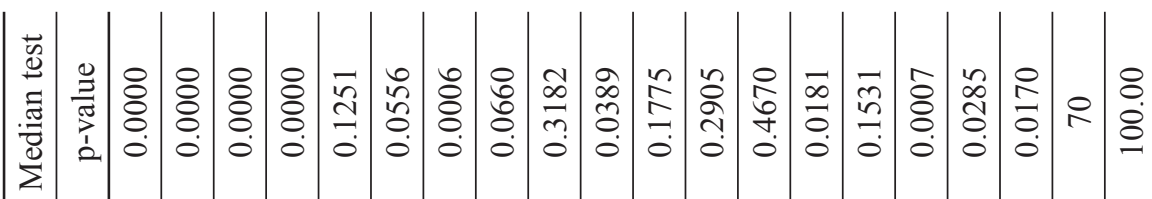

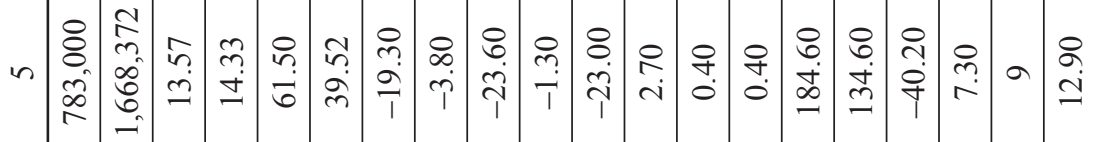

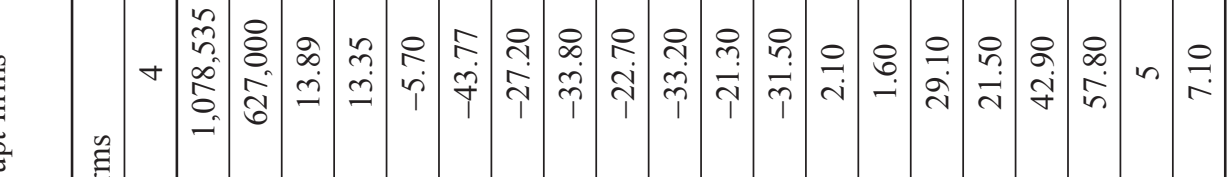

泀 泀

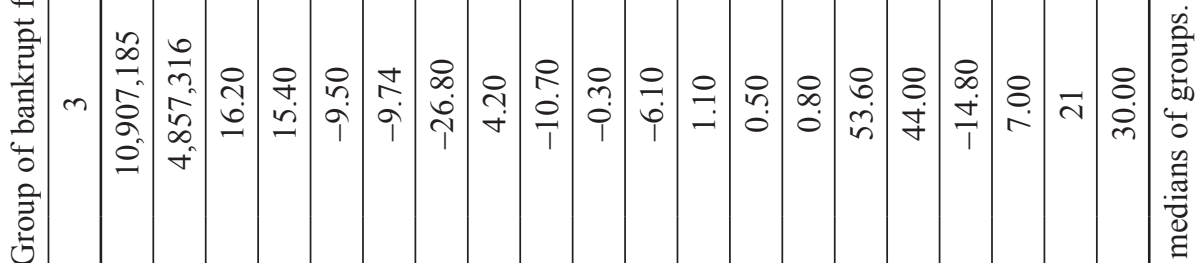

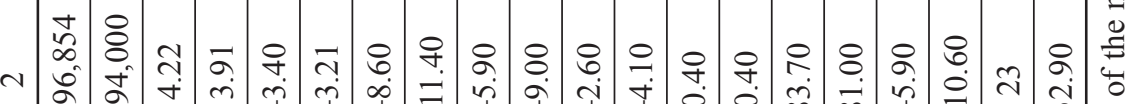

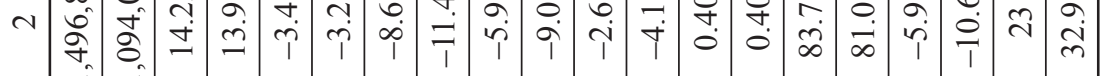
窝

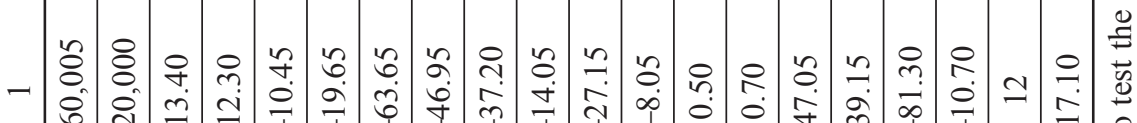

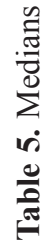

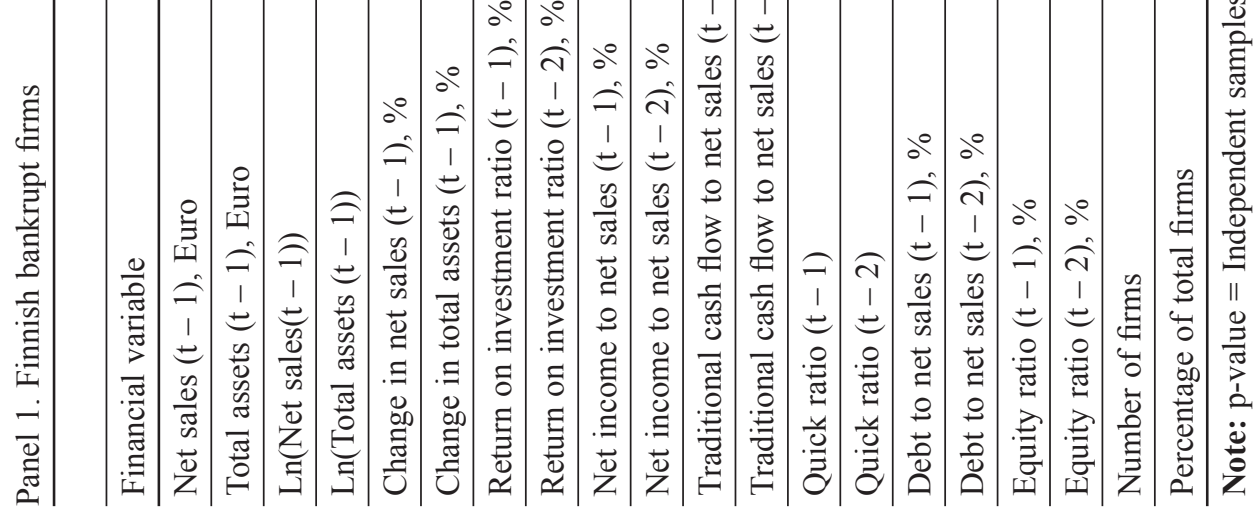




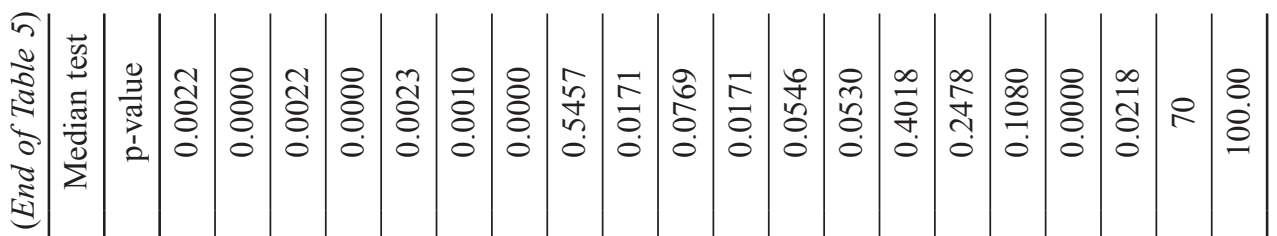

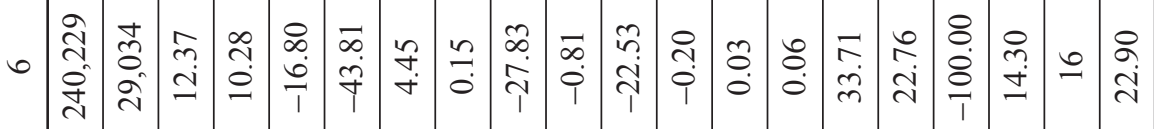

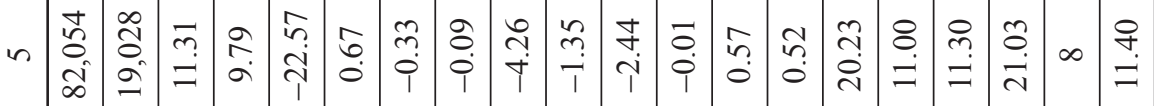

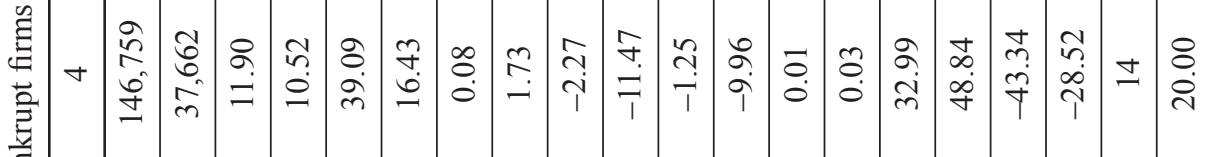

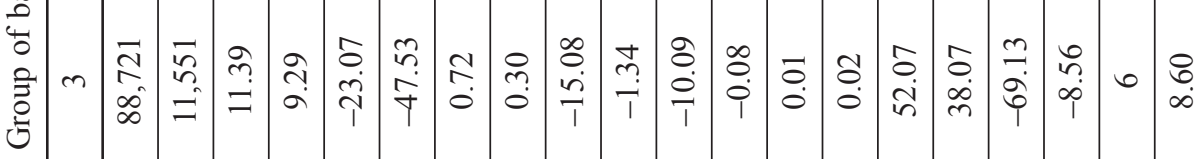

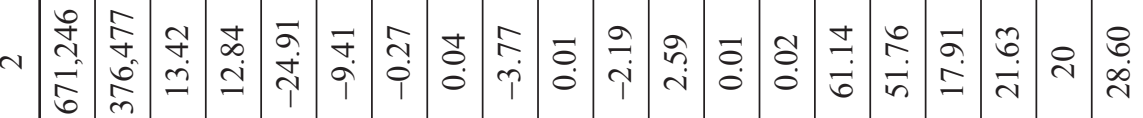

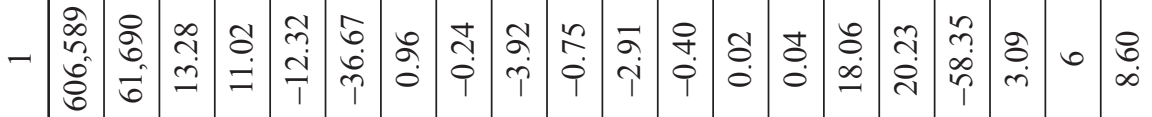

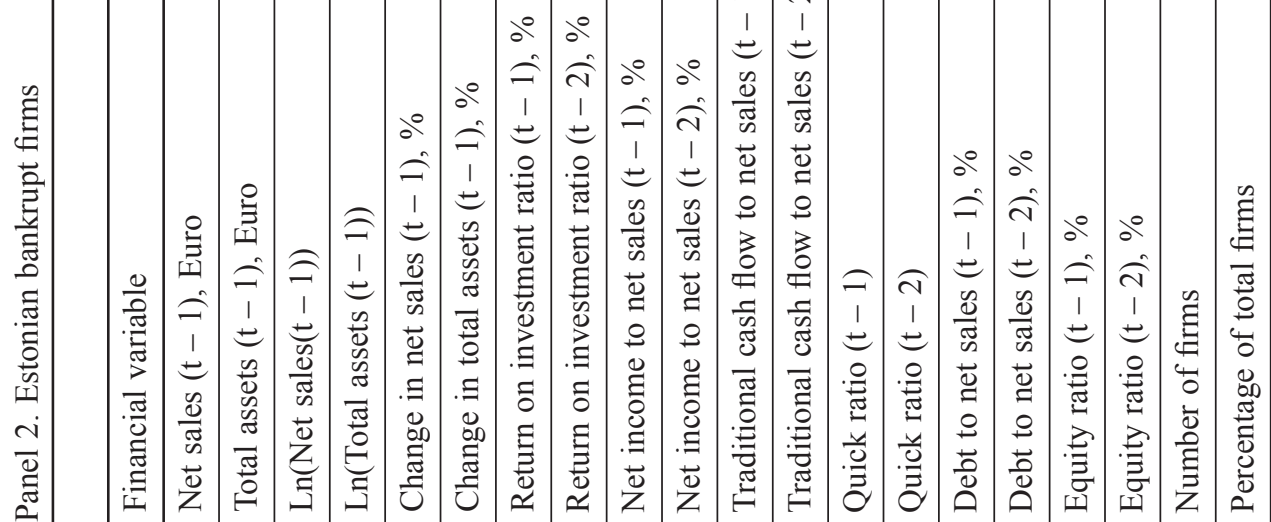


Panel 2 of Table 5 presents the six groups of Estonian bankrupt firms. The first group $(8.6 \%)$ is a small group including quite large firms (in Estonian terms) when measured by net sales which, however, have very little assets. In the first year before the bankruptcy event, the assets have declined remarkably. At the same time, the equity ratio has deteriorated in an extreme way. However, due to small assets, debt to net sales ratios stay almost steady at a low level. The second group (32.9\%) is the opposite of the first group. The firms in this group are quite large in net sales, but have an exceptionally large amount of assets. The financial situation of the firms has slightly deteriorated in the last year but due to large amount of assets, the equity ratio stayed at a high level. However, the firms show problems with high debt to net sales ratios. The third group $(8.6 \%)$ is small in number and consists of very small firms. The financial situation of these firms has significantly deteriorated in the first year before bankruptcy due to strong negative growth. In the last year, these firms report a very low cash flow, net income and equity ratios. The most striking point of the fourth group (20.0\%) is that the firms in this group show a very high positive growth. In other aspects, their financial situation is poor and does not differ from an average bankrupt firm in Estonia. The fifth group (11.4\%) shows a remarkable decline in net sales in the last year whereas total assets are steady. The profitability in this group does not differ from the average but liquidity and solidity are exceptionally high for an Estonian bankrupt firm. The firms in the sixth group $(22.9 \%)$ have little assets and in addition, they suffer from a strong negative growth in these assets. These firms are unsteady and show a dramatic decline in the first year prior to bankruptcy, especially in net income, cash flow, and equity ratios.

\subsection{Interrelations between Finnish and Estonian clusters}

The empirical results reported above indicate more failing firm types compared to findings in Argenti (1976), D'Aveni (1989) and Laitinen (1991). The factor solutions for Finnish and Estonian firms are very different. This result can be shown by the pairwise correlations between the factor scores presented in Panel 1 of Table 6. All the correlations are below 0.3 and only four out of 30 correlations $(5 \times 6)$ are statistically significant at the $0.1 \mathrm{p}$-level. Two of the four significant correlations are positive. Panel 2 of Table 6 shows the contingency table between the groupings of Finnish firms and their Estonian pairs. The dependence between the groupings is not statistically significant. However, the table shows that there is a remarkable dependence between Estonian group 4 and Finnish group 2 as well as between Estonian group 2 and Finnish group 3. Panel 1 of Table 6 shows that the correlations between the factors associated with these groups are positive and statistically significant. Thus, the Finnish and Estonian clusters of bankrupt firms are not strictly comparable but there are similarities between some clusters.

\subsection{Bankruptcy reasons by clusters}

Table 7 shows the averages of the reason variables for the Finnish and Estonian bankrupt firms by clusters. Panel 1 of Table 7 presents the averages for Finnish firms. Two of the reason variables show a significant difference between the groups. The firms in the first group have typically been bankrupted by poor financial management and 
Table 6. Dependence between Finnish and Estonian factors and groups Panel 1. Pearson correlations between factor scores in Estonian and Finnish bankrupt firms

\begin{tabular}{lccccc}
\hline \multicolumn{5}{c}{ Finnish factor } \\
\hline Estonian factor & 1 & 2 & 3 & 4 & 5 \\
\hline 1 & -0.049 & 0.067 & -0.009 & -0.206 & -0.018 \\
\hline$p$-value & 0.689 & 0.579 & 0.943 & 0.088 & 0.880 \\
\hline 2 & 0.041 & 0.063 & 0.277 & -0.110 & 0.035 \\
\hline$p$-value & 0.735 & 0.604 & 0.020 & 0.363 & 0.771 \\
\hline$p$-value & 0.028 & 0.060 & 0.036 & 0.134 & 0.103 \\
\hline 4 & 0.820 & 0.623 & 0.768 & 0.267 & 0.396 \\
\hline$p$-value & 0.039 & 0.276 & -0.134 & -0.038 & 0.046 \\
\hline 5 & 0.751 & 0.021 & 0.270 & 0.757 & 0.706 \\
\hline$p$-value & -0.169 & -0.193 & -0.031 & 0.028 & 0.089 \\
\hline$p$-value & 0.161 & 0.109 & 0.799 & 0.820 & 0.464 \\
\hline
\end{tabular}

Panel 2. Contingency table of Finnish and Estonian groups of bankrupt firms

\begin{tabular}{lccccccc}
\hline Estonian group & Finnish group & 1 & 2 & 3 & 4 & 5 & Total \\
\hline 1 & 0 & 2 & 3 & 1 & 0 & 6 \\
\hline 2 & 3 & 4 & 9 & 0 & 4 & 20 \\
\hline 3 & 0 & 3 & 1 & 1 & 1 & 6 \\
\hline 4 & 1 & 9 & 2 & 1 & 1 & 14 \\
\hline 5 & 4 & 2 & 0 & 1 & 1 & 8 \\
\hline 6 & 4 & 3 & 6 & 1 & 2 & 16 \\
\hline Total & 12 & 23 & 21 & 5 & 9 & 70 \\
\hline
\end{tabular}

Note: Pearson Chi-Square 27.203; p-value 0.130.

control and only rarely by any specific external event. The lack of financial control can largely explain the low profitability and the sudden decline in cash flow and equity ratio. The firms in the second group including average steady bankrupt firms also show average reasons for failure. However, they suffer quite seldom from lack of financial management and control, which can be the result of the steady (although poor) situation. The third group consists of large unsteady firms and shows a high frequency of external reasons. The firms in the fourth group show an exceptionally high liquidity and solidity. Therefore, it is natural that the main reasons of bankruptcy in this group deal with 


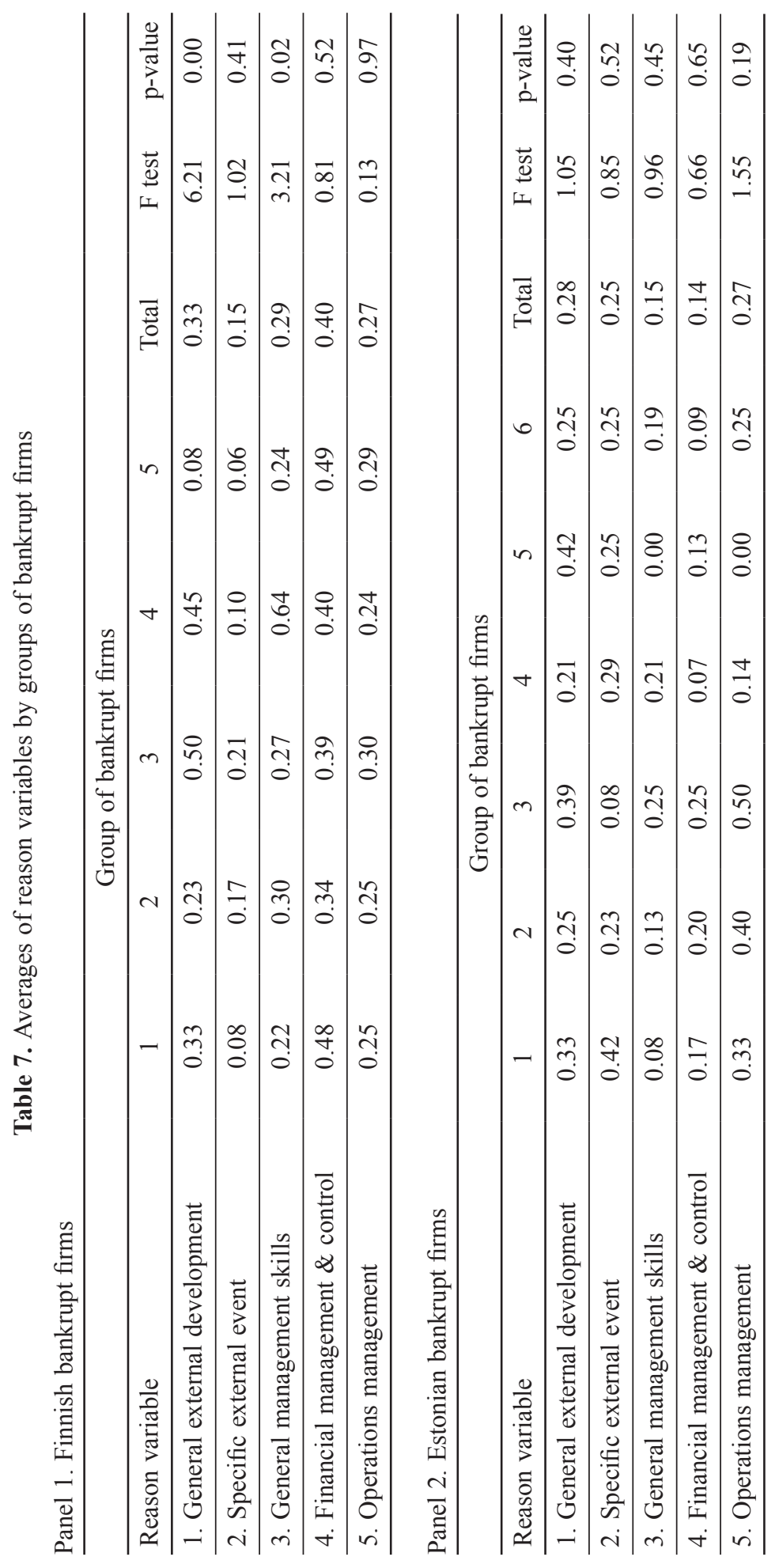


general external development and general management skills. The firms in the last group have grown rapidly and therefore the reasons are not external, but largely associated with financial management and control (of this growth).

Panel 2 of Table 7 presents the averages of reason variables for Estonian firms. None of the reasons show a statistically significant difference between the groups, mainly due to the very small number of firms in several groups. The firms in the first group have experienced a dramatic decline in the equity ratio which is often caused by a specific external event leading to bankruptcy. For the firms in the second group with a quite high equity ratio the reasons are distributed approximately in the same way as for an average bankrupt firm. The very small firms with negative growth in the third group mainly suffer from internal reasons of bankruptcy, especially problems in operations management. The firms in the fourth group show a very high growth rate and the reasons are, consequently, not associated with financial management and control or operations management. The firms in the fifth group suffer from a dramatic decline in net sales which may be due to general external development as a frequent reason for bankruptcy. These firms only rarely suffer from lack of general management skills or operations management. The firms in the last group tend to report a dramatic decline in several financial ratios before bankruptcy. However, they only rarely show any lack of financial management and control as a reason for bankruptcy.

Thus, empirical analysis of Finnish and Estonian failure processes shows that the financial processes and the reasons behind them are different. In Estonia as less developed economy, many bankrupt firms suffer from lack of elasticity for specific external events. In a developed economy as Finland, internal reasons such as lack of financial management and control may be present in most failure processes.

\section{Conclusions}

The purpose of this paper was to investigate whether the failure processes described using financial variables and reasons for bankruptcy differ through countries. Based on the sample of paired Estonian and Finnish bankrupt firms, it was established that companies from these two countries are remarkably different before the bankruptcy moment. Specifically, Finnish and Estonian firms are discriminated by variables of size (total assets), profitability, liquidity and solidity at a very high rate of precision. Estonian firms show a very low liquidity, but better profitability than their Finnish pairs. The results indicate that in a less developed economy bankruptcy is often a consequence of a liquidity crisis while in a more developed economy it is usually caused by profitability crisis. Both of these crisis types will lead as a process to a collapse in solidity reflected by the equity ratio. The analysis showed that the taxonomies of failure processes based on financial variables significantly differ in Finland and Estonia, even despite the fact that analysed firms in these countries are pairs. Thus, selected two countries vary a lot and a general taxonomy cannot be extracted. 
The model of non-financial failure variables (bankruptcy reasons) was not as successful as financial variables in discriminating firms from two countries, indicating that for similar failed firms in two different environments the non-financial reasons for failure could be more alike than financial ones. Still, in a more developed country as Finland, bankruptcies are often caused by lack of management skills (i.e. internal reasons), whereas in Estonia (specific) external events are frequent as a cause of bankruptcy. Thus, it seems that in more developed countries business survival is strongly connected with management and control skills while in less developed ones the main challenge comes from the pressures of economic environment. Frequencies of failure reasons differ through established financial failure processes, indicating that different failure causes are connected with different financial variables. Still, statistically significant differences were found only in case of Finnish firms.

The present study suffers from limitations. Firstly, a limitation that could be relaxed in future research concerns the classification of non-financial reasons for failure, as several transformations were needed to obtain comparable groups of reasons for analysis. In future studies, special attention should be paid to gathering the basic information of reasons using the same classification scheme. Secondly, an inevitable limitation in this study was the matching of firms, which based on the available data, was conducted in the best possible way for the current analysis. Still, the authors acknowledge that selection of different pairs could alter the results and in future research, this pairwise sampling could be improved by paying more attention to match the size of pairs. Also, although laws are similar in two countries analysed, their implementation can vary, so the impact of differences in the implementation of laws on failure processes is a topic that can be studied further. We hope that this pioneering study will lead to a trend of studies focusing on differences in failure processes across various countries.

\section{Acknowledgements}

Financial support from Jenny and Antti Wihuri Foundation in Finland, Foundation for Economic Education in Finland and Estonian Research Council grant IUT20-49 "Structural Change as the Factor of Productivity Growth in the Case of Catching up Economies" is gratefully acknowledged. Authors thank Andrew Rozeik and two anonymous reviewers for comments that lead to the improvement of this paper.

\section{References}

Altman, E.; Haldeman, R. G.; Narayanan, P. 1977. ZETA ${ }^{\mathrm{TM}}$ analysis. A new model to identify bankruptcy risk of corporations, Journal of Banking and Finance 1(1): 29-54.

http://dx.doi.org/10.1016/0378-4266(77)90017-6

Argenti, J. 1976. Corporate collapse: the causes and symptoms. New York: McGraw-Hill.

Balcaen, S.; Ooghe, H. 2006. 35 years of studies on business failure: an overview of the classic statistical methodologies and their related problems, The British Accounting Review 38(1): 63-93. http://dx.doi.org/10.1016/j.bar.2005.09.001

Baldwin, J.; Gray, T.; Johnson, J.; Proctor, J.; Raffiquzamann, M.; Sabourin, D. 1997. Failing concerns: business bankruptcy in Canada. Ottawa: Analytical Studies Branch, Statistics Canada. 
Baležentis, A.; Baležentis, T.; Valkauskas, R. 2010. Evaluating situation of Lithuania in the European Union. Structural indicators and MULTIMOORA method, Technological and Economic Development of Economy 16(4): 578-602. http://dx.doi.org/10.3846/tede.2010.36

Bellovary, J. L.; Giacomino, D. E.; Akers, M. D. 2007. A review of bankruptcy prediction studies: 1930 to present, Journal of Financial Education 33(4): 3-41.

Boyle, R. D.; Desai, H. B. 1991. Turnaround strategies for small firms, Journal of Small Business Management 29(3): 33-42.

Cochran, A. B. 1981. Small business mortality rates: a review of the literature, Journal of Small Business Management 19(4): 50-59.

Crutzen, N.; Van Caillie, D. 2010. Towards a taxonomy of explanatory failure patterns for small firms: a quantitative research, Review of Business and Economics 55(4): 438-462.

D'Aveni, R. 1989. The aftermath of organizational decline: a longitudinal study of the strategic and managerial characteristics of declining firms, Academy of Management Journal 32(3): 577-605. http://dx.doi.org/10.2307/256435

Daily, C. M. 1994. Bankruptcy in strategic studies: past and promise, Journal of Management 20(2): 263-295. http://dx.doi.org/10.1177/014920639402000202

Dimitras, A. I.; Zanakis, S. H.; Zopounidis, C. 1996. A survey of business failures with an emphasis on prediction methods and industrial applications, European Journal of Operational Research 90(6): 487-513. http://dx.doi.org/10.1016/0377-2217(95)00070-4

EBRD. 2011. Transition report 2011. Crisis and transition: the people's perspective. London: European Bank for Reconstruction and Development.

Eurostat database. 2012. [Online], [cited 29 May 2012]. Available from Internet:

http://ec.europa.eu/eurostat

Everett, J.; Watson, J. 1999. Small business failure rates: choice of definition and industry effects, International Small Business Journal 17(2): 31-47. http://dx.doi.org/10.1177/0266242699172002

Fredland, J. E.; Morris, C. E. 1976. A cross section analysis of small business failure, American Journal of Small Business 1(1): 7-18.

Gaskill, L.-A. R.; Manning, R. A.; Van Auken, H. E. 1993. A factor analytic study of the perceived causes of small business failure, Journal of Small Business Management 31(4): 18-31.

Hambrick, D. C.; D’Aveni, R. 1988. Large corporate failures as downward spirals, Administrative Science Quarterly 33(1): 1-23. http://dx.doi.org/10.2307/2392853

Hofstede, G. 2012. National culture dimensions [online], [cited 29 May 2012]. Available from Internet: http://www.geert-hofstede.com

Jones, F. 1987. Current techniques in bankruptcy predicting, Journal of Accounting Literature 6: 131-164.

Kornai, J. 2006. The great transformation of Central Eastern Europe. Success and disappointment, Economics of Transition 14(2): 207-244. http://dx.doi.org/10.1111/j.1468-0351.2006.00252.x

Laitinen, E. 1993. Financial predictors for different phases of firm failure, Omega 21(2): 215-228. http://dx.doi.org/10.1016/0305-0483(93)90054-O

Laitinen, E. 1991. Financial ratios and different failure processes, Journal of Business Finance \& Accounting 18(5): 649-673. http://dx.doi.org/10.1111/j.1468-5957.1991.tb00231.x

Lensberg, T.; Eilifsen, A.; McKee, T. E. 2006. Bankruptcy theory development and classification via genetic programming, European Journal of Operational Research 169(2): 677-697.

http://dx.doi.org/10.1016/j.ejor.2004.06.013

Lussier, R. N.; Halabi, C. E. 2010. A three-country comparison of the business success versus failure prediction model, Journal of Small Business Management 48(3): 360-377.

http://dx.doi.org/10.1111/j.1540-627X.2010.00298.x 
Lussier, R. N.; Pfeifer, S. 2001. A crossnational prediction model for business success, Journal of Small Business Management 39(3): 228-239. http://dx.doi.org/10.1111/0447-2778.00021

Masso, J.; Vahter, P. 2008. Technological innovation and productivity in post-transition Estonia: econometric evidence from innovation surveys, European Journal of Development Research 20(2): 240-261. http://dx.doi.org/10.1080/09578810802060751

Mellahi, K.; Wilkinson, A. 2004. Organizational failure: a critique of recent research and a proposed integrative framework, International Journal of Management Reviews 5(1): 21-41. http://dx.doi.org/10.1111/j.1460-8545.2004.00095.x

Moulton, W. N.; Thomas, H.; Pruett, M. 1996. Business failure pathways: environmental stress and organizational response, Journal of Management 22(4): 571-595.

http://dx.doi.org/10.1177/014920639602200403

Ooghe, H.; Balcaen, S. 2007. Are failure prediction models widely usable? An empirical study using a Belgian dataset, Multinational Finance Journal 11(1/2): 33-76.

Ooghe, H.; De Prijcker, S. 2008. Failure processes and causes of company bankruptcy: a typology, Management Decision 46(2): 223-242. http://dx.doi.org/10.1108/00251740810854131

Pretorius, M. 2008. Critical variables of business failure: a review and classification framework, South African Journal of Economic and Management Sciences 11(4): 408-430.

Richardson, B.; Nwankwo, S.; Richardson, S. 1994. Understanding the causes of business failure crises. Generic failure types: boiled frogs, drowned frogs, bullfrogs and tadpoles, Management Decision 32(4): 9-22. http://dx.doi.org/10.1108/00251749410058635

Scott, J. 1981. The probability of bankruptcy, Journal of Banking and Finance 5(3): 317-344. http://dx.doi.org/10.1016/0378-4266(81)90029-7

Sheppard, J. P.; Chowdhury, S. D. 2005. Riding the wrong wave: organizational failure as a failed turnaround, Long Range Planning 38(3): 239-260. http://dx.doi.org/10.1016/j.lrp.2005.03.09

World Bank. 2012. Doing business database [online], [cited 29 May 2012]. Available from Internet: http://www.doingbusiness.org

World Economic Forum. 2012. The Europe 2020 competitiveness report: building a more competitive Europe. Geneva: World Economic Forum. 


\section{Appendix}

\section{Varimax-rotated factor loadings}

Panel 1. Finnish bankrupt firms

\begin{tabular}{|c|c|c|c|c|c|}
\hline \multirow[b]{2}{*}{ Financial variable } & \multicolumn{5}{|c|}{ Loadings on factors } \\
\hline & 1 & 2 & 3 & 4 & 5 \\
\hline $\operatorname{Ln}($ Net sales $(t-1))$ & 0.375 & 0.216 & 0.845 & 0.025 & 0.010 \\
\hline $\operatorname{Ln}($ Total assets $(\mathrm{t}-1))$ & -0.079 & 0.085 & 0.924 & 0.126 & 0.054 \\
\hline Change in net sales $(t-1), \%$ & -0.121 & 0.153 & 0.081 & -0.108 & 0.794 \\
\hline Change in total assets $(\mathrm{t}-1), \%$ & 0.138 & 0.067 & 0.001 & 0.025 & 0.872 \\
\hline $\begin{array}{l}\text { Return on investment ratio } \\
(\mathrm{t}-1), \%\end{array}$ & 0.111 & 0.883 & 0.062 & 0.141 & 0.024 \\
\hline $\begin{array}{l}\text { Return on investment ratio } \\
(\mathrm{t}-2), \%\end{array}$ & 0.116 & 0.590 & 0.388 & 0.168 & 0.333 \\
\hline $\begin{array}{l}\text { Net income to net sales } \\
(\mathrm{t}-1), \%\end{array}$ & 0.518 & 0.765 & 0.134 & -0.130 & 0.140 \\
\hline $\begin{array}{l}\text { Net income to net sales } \\
(\mathrm{t}-2), \%\end{array}$ & 0.672 & 0.571 & 0.210 & 0.097 & 0.168 \\
\hline $\begin{array}{l}\text { Traditional cash flow to net sales } \\
(\mathrm{t}-1), \%\end{array}$ & 0.546 & 0.747 & 0.158 & -0.164 & 0.141 \\
\hline $\begin{array}{l}\text { Traditional cash flow to net sales } \\
(\mathrm{t}-2), \%\end{array}$ & 0.688 & 0.541 & 0.216 & 0.055 & 0.178 \\
\hline Quick ratio $(\mathrm{t}-1)$ & -0.031 & -0.057 & -0.265 & 0.703 & -0.288 \\
\hline Quick ratio $(\mathrm{t}-2)$ & 0.146 & -0.483 & 0.186 & 0.554 & -0.034 \\
\hline Debt to net sales $(t-1), \%$ & -0.909 & -0.224 & -0.033 & -0.120 & 0.086 \\
\hline Debt to net sales $(\mathrm{t}-2), \%$ & -0.965 & -0.008 & -0.026 & -0.137 & 0.034 \\
\hline Equity ratio $(\mathrm{t}-1), \%$ & 0.158 & 0.465 & 0.219 & 0.757 & 0.043 \\
\hline Equity ratio $(\mathrm{t}-2), \%$ & 0.153 & 0.053 & 0.462 & 0.724 & 0.200 \\
\hline
\end{tabular}

Panel 2. Estonian bankrupt firms

\begin{tabular}{lcccccc}
\hline & \multicolumn{7}{c}{ Loadings on factors } \\
\hline Financial variable & 1 & 2 & 3 & 4 & 5 & 6 \\
\hline Ln(Net sales $(\mathrm{t}-1))$ & 0.355 & 0.706 & 0.201 & -0.017 & -0.420 & 0.061 \\
\hline Ln(Total assets $(\mathrm{t}-1))$ & -0.123 & 0.901 & 0.122 & 0.163 & -0.247 & 0.067 \\
\hline Change in net sales $(\mathrm{t}-1), \%$ & 0.201 & -0.162 & -0.013 & 0.774 & -0.232 & 0.150 \\
\hline Change in total assets $(\mathrm{t}-1), \%$ & 0.025 & 0.241 & -0.267 & 0.775 & 0.132 & -0.122 \\
\hline $\begin{array}{l}\text { Return on investment ratio } \\
(\mathrm{t}-1), \%\end{array}$ & 0.123 & -0.167 & 0.021 & -0.362 & -0.011 & 0.613 \\
\hline
\end{tabular}


(End of Appendix)

\begin{tabular}{lcccccc}
\hline $\begin{array}{l}\text { Return on investment ratio } \\
(\mathrm{t}-2), \%\end{array}$ & -0.061 & 0.191 & -0.010 & 0.248 & 0.019 & 0.707 \\
\hline Net income to net sales $(\mathrm{t}-1), \%$ & 0.784 & 0.059 & 0.283 & 0.457 & 0.017 & -0.054 \\
\hline Net income to net sales $(\mathrm{t}-2), \%$ & 0.159 & 0.254 & 0.914 & -0.105 & 0.090 & 0.007 \\
\hline $\begin{array}{l}\text { Traditional cash flow to net sales } \\
(\mathrm{t}-1), \%\end{array}$ & 0.792 & 0.144 & 0.291 & 0.439 & 0.036 & -0.059 \\
\hline $\begin{array}{l}\text { Traditional cash flow to net sales } \\
(\mathrm{t}-2), \%\end{array}$ & -0.087 & 0.244 & 0.944 & -0.095 & 0.093 & 0.015 \\
\hline Quick ratio $(\mathrm{t}-1)$ & 0.135 & -0.040 & 0.086 & 0.006 & 0.808 & -0.210 \\
\hline Quick ratio $(\mathrm{t}-2)$ & 0.057 & -0.025 & 0.098 & -0.092 & 0.725 & 0.382 \\
\hline Debt to net sales $(\mathrm{t}-1), \%$ & -0.959 & 0.027 & 0.025 & -0.035 & -0.063 & -0.102 \\
\hline Debt to net sales $(\mathrm{t}-2), \%$ & -0.870 & 0.004 & 0.235 & 0.242 & -0.117 & -0.003 \\
\hline Equity ratio $(\mathrm{t}-1), \%$ & 0.107 & 0.720 & 0.354 & 0.218 & 0.359 & -0.197 \\
\hline Equity ratio $(\mathrm{t}-2), \%$ & -0.013 & 0.689 & 0.308 & -0.300 & 0.359 & 0.120 \\
\hline
\end{tabular}

Erkki K. LAITINEN is a Professor of Accounting and Business Finance at University of Vaasa. His research has been focused on default risk prediction, reorganization of business firms, pricing decisions, financial statement analysis, quantitative analysis, optimization models, performance measurement systems, company valuation, company risk assessment, management accounting. He has published over 100 papers, among them in various top journals.

Oliver LUKASON is a Research Fellow at University of Tartu. His research has been focused on different facets of firm failure and survival, e.g. firm failure causes, bankruptcy prediction, firm reorganization, survival and performance of start-up and spin-off firms, credit scoring, which have been published both, as international journal articles and monograph chapters. 